\title{
Portrayal of "Oud" Musical Instrument in Creative Work of Alisher Navoi
}

\author{
Laylo Djuraeva \\ Uzbekistan State Conservatory, Tashkent, Uzbekistan
}

\begin{abstract}
The Oud is a pear-shaped stringed instrument with 11 or 13 strings grouped in 5 or 6 courses, commonly used in Persian, Arabic, Greek, Turkish, Jewish, Byzantine, Azerbaijani, Armenian, North African and Middle Eastern music. Oud had been widely popular before 17th century among society, and it provided moral and spiritual nourishment. This musical instrument was created by singer Borbad who lived in the period of Khisrav Parviz who was Sosoniy King and it was in the novel of "Khisrav and Shirin" (Nizami Ganjavi). Oud was also described in Kitab al-Musiqa al-Kabir (The Book of Music) by Farabi. Moreover, Alishir Navoi showed the connection of the science of music with spiritual world in verses of his priceless heritage. The poet assessed the sound features of the musical instruments in his book Mahbub ul-Qulub. Additionally he has written, "While the sound of Chang (struck zither) is torturing, sound of Oud is more touching." Sometimes Navoi used the Oud in musician's hands as an artistic image in order to illustrate his torture to reader. He described his condition very vividly and skillfully. This is probably because Oud has unique wail, which cannot be heard in any other instruments.
\end{abstract}

Keywords: Navoi, Oud, Mughanni, ghazal, musical instrument, verses

\section{Introduction}

Mir Alisher Navoi (1441, February 9 Herat - 1501, January 3 the same city) lived and worked during the period of Timurids' reign. He was a highly estimated and adored man of his time in Persian and Turkic dwellings as the greatest poet, scholar and political leader. If we look more thoroughly into the contents and essence of his books, we can note the peculiar interpretation done by him concerning all religious, philosophic and mystic viewpoints existed in the Eastern Lands at that time. Navoi's dastans (poems) and gazelles (a genre of Oriental poetry) are deeply soaked with broad scientific, literary, religious, philosophic ideas that demand of a reader great knowledge to understand and interpret most of his gazelles. Moreover, without any doubt the influence of such famous Persian poets as Farid ad-din Attar, Kasim Anvor, Hafiz Sherazi on Navoi's outlooks was immense.

\section{Uzbek Music}

The history of Uzbek music is very rich and antique. In the past, various musical instruments were used in everyday life, hunting, kingdom, cultural celebrations, and national parades. Musical instruments throughout the centuries satisfied people's spiritual needs and developed over the centuries. Harp, tube and wind instruments have the longest and the most ancient history (Erkinov, 1998). Tanbur (long-necked fretted lute),

Laylo Djuraeva, Ph.D. student, musician-literary, Uzbekistan State Conservatory. 
Gijjak (Kemenche - spike fiddle), Ney (side-blown flute), Kanun, Dutar, Rubab and other various types of musical instruments were created on the basis of the above mentioned ones (Nemati Limai, 2015). One of them - Oud — had been widely popular before XVII century among society, and it provided moral and spiritual nourishment. Its first known shape was reflected in cultural heritage found in Ayritom in I century AD (Alisher, 1987-2002).

It is known that Oud played an important role in the history of music art. In particular, it is clear from the books of scientists, who studied musical science, that the instrument's strings and frets were used to explain music theory.

"Oud" is an Arabic word which has different meanings. Oud was a tree which exuded fragrant aroma while burning. Probably, Oud was originally made of wood of the same tree (Subtelny, 1979-1980). On the other hand, if it was taken from the word "Eid" which describes the joy, celebration, holidays, that could also mean "the instrument that gives the mood of merriment". It is indicated in some sources that its first name was "barbat". The meaning of "barbat bar"-shape, "bat"-a duck, which means a musical instrument with big belly and shorts handle (Allworth, 1990).

Its history goes back to long past. Several centuries ago, a duck-shaped musical instrument named "barbat" was invented. This musical instrument was created by singer Borbad who lived in the period of Khisrav Parviz who was Sosoniy King and it was in the novel of "Khisrav and Shirin" (Nizami Ganjavi's work) which was translated by Kutb Khorasmi. And it is said that one of his first musical instruments was that instrument (Encyclopaedia Iranica, n.d.).

Nevertheless, it has become clear that barbat was invented long before Borbad's time, and that he was a skillful player of barbat. It improved over the centuries, and at times of Abu Nasr Farabi, it had four strings.

Many theoreticians of the past wrote information about Oud in their treatises.

Oud instrument was described in Kitab al-Musiqa al-Kabir (The Book of Music) by Farabi. It is written in this book, "Famous singer and musician Mansur Zalzal (721-731) was from the city Ray near Tehran. He invented short-handled Oud and adjusted its mood" (Abdullaev, 2002).

Farabi has also known well to play the instrument Oud.

Safiuddin Urmaviy was also Oud player who wrote his theoretical rules based on experiments held. It is said that the word "Oud" existed in treatises in Central Asia until XVII century (Allworth, 1990; Encyclopaedia Iranica, n.d.). Nowadays it plays an important role in music art of the people of Caucasus, Iran, the Arabs, the Turkish, and many European people. It is famous with the name "lute" in Europe. Oud, which is commonly spread in the East, has bigger belly than dutar, and it is round-shaped with a short handle. It is clear from miniatures that there were various types of an ancient Oud with long handles.

The ways to make of Bo'd (Interval), gender (tetrachord, pentachord), jam' (voice line) were seen clearly through strings of Oud (Navoi, 2002; Nemati Limai, 2015).

Forobiy, Avicenna, Sheroziy, Khusayni, and Omuli, who deeply studied scientific-theoretical features of the music, mentioned in their own musical treatises that stringed instruments were the most convenient for expressing and interpreting theoretical issues of music and so that they had chosen Oud musical instrument, which was widely used in that period.

1 The same source, p. 17. 
Alishir Navoi showed the connection of the science of music with spiritual world in the bytes of his priceless heritage. We can see information about some instruments, especially about the sound, tone, and appearance of Oud, in verses of Navoi. The poet assessed the sound features of the musical instruments in the book Mahbub ul-Qulub, and also wrote, "While chang's sound is torturing, Oud's sound is more touching." Sometimes Navoi used the Oud in musician's hands as an artistic image in order to illustrate his torture to a reader. He described his condition very vividly and skillfully. In fact, this is probably because Oud has unique wail, which cannot be heard in any other instruments (Allworth, 1990).

Navosidin fano chun hosil o'ldi qilg'aysen, ey ishq,

Navoiy rishtai jonin mug'anniy udining tori. (Navoi, 1988, Vol. 2)

Because strings of Mughanni or musician's instruments are made of soul of Navoi, its music created this evanescent world. Loving people, be aware that when a musician starts playing his instrument and you realize that everything in this world is evanescent, then, the strings of the musician's instrument are made of Navoi's soul.

Navai' mainly says that the sound is painful because it is made of the strings of his soul; on the other hand, he states that the instrument sings about evanescent world and connects it with theology. It is shown in different view in other byte:

Mayg'a ohang et, Navoiykim, mug'anniy har zamon

Aysh taxrisin ayon aylar lisoni ud ila. (Navoi, 1997, Vol. 6)

Hey Navoi, intend to achieve wine, aspire that, because mughanniy every time elucidate passion of life, namely what it is pleasure of, delectation of the world. More understandable words are the world of the spirit finds comfort and entire life strive to reach for attaining gardens of paradise and achieving to see God. The pathway for getting these is, indeed, a good deed and worship. We can understand the verses in above, Navoi portrays that the explained same passion with Oud tongue.

...Uddek kuymakligim sharx et lisoni hol ila,

Nag'mada udning lisonin sehri pardoz aylasang. (Navoi, 1997, Vol. 6)

The poet gives the word Oud ambiguously — as a tree which exudes fragrant aroma while burning (Expert of Maqams I. Rajabov states in his studies that Oud was named after that tree) and as a musical instrument.

Sarxush taronagustar bo'lmishsen, ey Navoiy,

Soqiy, sen emdi may tut, mutrib, sen emdi tuz ud. (Navoi, 1993, Vol. 4)

Navoi started to share the music while being drunk in love, Saki, pour your drinks, musician, start playing your magical music. In this byte, Navoi stated that the music has divine power and that Oud is also closely related to divine.

$\mathrm{Bu}$ dayr ichra Navoe, ey mug'anniy,

Navoiy nolasidek zeru bam tuz. (Navoi, 1998, Vol. 7) 
Hey Mughanni, make "Zer" and "Bam" as Navoi's wail among the wails of this church. Here zer and bam may mean the sounds of strings. Nevertheless, we may see in old sources that these strings were Ouds' lower-big and upper-high strings and Navoi' wrote quite many bytes dedicated to those strings.

\section{Conclusion}

It can be concluded that Oud was not only used to explain, describe, and understand theoretical music, but also a magical instrument, which made people's souls both calm and riotous with its pathetic, pleasant and soft sound. If we talk from the point of view of Navoi', peace is when a life scenery flashes before the eyes of a person while slowly approaching a better world, and because of being sure about the end of destination, it is very calm in the heart. Riot is a feeling when a person loses his way.

The word Oud was used to explain theoretical music. However, Navoi' showed Oud in his works as a musical instrument, which can enter people's spiritual world, a magical instrument which conquered souls with its sound.

\section{References}

Abdullaev, R. (2002). Alisher Navoi in Mutal Burkhonov's work. Music Art Issue.: "The new generation of the century".

Allworth, E. A. (1990). The modern Uzbeks: From the fourteenth century to the present: A cultural history. Stanford: Hoover Institution Press.

Encyclopaedia Iranica. (n.d.). Barbat. Retrieved from http://www.iranicaonline.org/articles/barbat

Erkinov, A. (1998). The perception of works by classical authors in the 18th and 19th centuries Central Asia: The example of the Khamsa of Alisher Navoi. Publishing city: publisher.

Gafurbekov, T. (1987). Creative monody national resources and their interpretation in Uzbek Soviet music. T: . Science.

Ibrokhimov, O. (2002). Sir Navoi and Maqom. Music Art. Issue.: "The new generation of the century".

Karimov, Z. G. (1988). Navoi in music. - Is.: Literature and Art named after Gafur Gulam.

Michael, K., \& Allen, F. (n.d.). Muslim culture in Russia and Central Asia from the 18th to the early 20th centuries (pp. 508-521). Berlin: Merve Verlag.

Nabiyeva, M. (2002). Alisher Navoi poetry in the works of composers in 1990. Music Art Issue.: "Generation of the new century".

Navoi, A. (1987-2002). New collection of complete works in 20 volumes (Vols. 1-18). Tashkent: "Yangi Asr Avlodi".

Nemati Limai, A. (2015). Analysis of the political life of Amir Alisher Navai and exploring his cultural, scientific, social and economic works. Tehran \& Mashhad: MFA (Cire) \& Ferdowsi University.

Subtelny, M. E. (1979-1980). AlīShīr Navā'̄ì: Bakhshī and Beg. Eucharisterion: Essays presented to Omeljan Pritsak on his sixtieth birthday by his colleagues and students. Harvard Ukrainian Studies, 3(4), 799. 